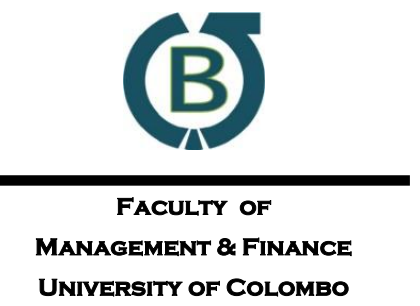

\title{
Successful Implementation of the Balanced Scorecard in a Telecommunications Firm: An Institutional Theory Analysis
}

\author{
Kalani Thananchayan ${ }^{\mathrm{a}}$, Tharusha Gooneratne $\mathrm{a}^{\mathrm{a}}$ \\ ${ }^{a}$ Department of Accounting, University of Colombo, Sri Lanka
}

\begin{abstract}
This paper explores how a balanced scorecard (BSC) has been successfully implemented and institutionalised in a leading telecommunications company in Sri Lanka (Telinotec) through improvements over two phases (pre 2012 and post 2012). It adopts a qualitative methodology and case study approach and is founded upon the theoretical underpinnings of institutional theory, more specifically the institutionalisation model of Tolbert and Zucker (1996). The findings suggest that while the BSC was implemented in 2000, improvements via linking it to individual performance and the corporate strategy were done after 2012. This paper contributes to literature by illuminating how the BSC was initiated (habitualisation), translated into practice (objectification) and institutionalised (sedimentation) in a firm and offers insights to practitioners on making management accounting tools successful by continuously modifying to match managers' expectations and the context of the firm.
\end{abstract}

Keywords: Balanced scorecard, Case study, Institutional theory, Telecommunications firm, Institutionalisation model of Tolbert and Zucker

$\begin{array}{lll}\text { Received: } & \text { Accepted revised version: } & \text { Published: } \\ \text { 13 March 2018 } & \text { 20 September 2018 } & \text { 31 December 2018 }\end{array}$

Suggested citation: Thananchayan, K. \& Gooneratne, T. (2018). Successful implementation of the balanced scorecard in a telecommunications firm: An institutional theory analysis. Colombo Business Journal. (9)2, 26-52

DOI: http://doi.org/10.4038/cbj.v9i2.35

(C) 2018 The Authors. This work is licenced under a Creative Commons Attribution 4.0 International Licence which permits unrestricted use, distribution, and reproduction in any medium, provided the original work is properly cited.

\tharushng@dac.cmb.ac.lk: (iD) https://orcid.org/0000-0003-1294-3236 


\section{Introduction}

When competing in the dynamic business environment, organisations need to capture financial as well as non-financial performance through a multitude of indicators (Johnson \& Kaplan, 1987). This has led to the development of various management accounting tools in the contemporary business settings, including the balanced scorecard (BSC), which integrates financial and non-financial indicators into a single performance management report. The BSC measures the performance of a business firm across four inter-related perspectives, which include financial, customer, internal business processes and learning and growth (Kaplan \& Norton, 1992, 1996). The BSC is not merely a collection of financial and non-financial measures, it is derived from the organisation's vision, and is a means to translate the mission and strategy into a set of key performance indicators (KPIs), while forming the foundation for the strategic management system of a firm (Kaplan \& Norton, 2004).

After it was first introduced by Robert Kaplan and David Norton through their influential article in 1992, over the past 25 years, the BSC has attracted widespread interest from academics and business firms across different industries, from manufacturing to service, and from public to private sector. The current body of literature covers its implementation and use (Ahn, 2001; Butler, Letza, \& Neale, 1997; Malmi, 2001; Papalexandris, Ioannou, \& Prastacos., 2004; Speckbacher, Bischof, \& Pheiffer, 2003), relationship to firm performance (Davis \& Albright, 2004; Hoque \& James, 2000), effectiveness as a device for strategy communication and management control (Malina \& Selto, 2001), as well as criticisms (Norreklit, 2000, 2003; Epstein \& Manzoni, 1998; Kasurinen, 2002). Notwithstanding this, an array of studies, review papers, special issues and other contributions suggest that BSC still warrants scholarly inquiry (Hoque, 2014), for in the extant BSC research relatively few success stories have been reported. More insights into application and use of the BSC will therefore be of value to researchers and practitioners grappling with its implementation in business firms (Hoque, 2014; Madsen \& Stenheim, 2015).

Furthermore, Andon, Baxter, and Mahama (2005, p. 36) has noted, "we have limited understanding of the socio-political and organisational practices enabling the BSC to emerge and endure, and there is need for research grounded in social and critical theory to supplement the existing body of knowledge about BSC". Responding to this call, this paper draws theoretical insights from institutional theory, more specifically the institutionalisation model of Tolbert and Zucker (1996), which illuminates how institutionalisation occurs in three stages (pre-institutional, semi- 
institutional and full-institutionalisation) characterised by three sequential processes (habitualisation, objectification and sedimentation). Accordingly, this research explores how the BSC has been successfully implemented and has become an institutionalised organisational practice drawing empirical evidence from a Sri Lankan telecommunications firm (Telinotec), in which the BSC has been in practice for a period nearing two decades. Telinotec is a suitable context for this paper, for, although the BSC has turned to be a popular management accounting tool even among Sri Lankan managers, most organisations fail to integrate it with their routine tasks (Wickramasinghe, Gooneratne, \& Jayakody, 2008). Additionally, there is little understanding in the current literature on how BSC can be successfully implemented and sustained. Therefore, this paper addresses the research question; how has the case firm implemented and institutionalised the BSC. The findings of this research is a useful addition to the current body of management accounting knowledge. Though the institutionalisation model of Tolbert and Zucker (1996), on which this paper is founded, is a suitable theoretical lens, it has scarcely been used in understanding the institutionalisation of management accounting tools. This study thus contributes to theory by extending the use of this model to the area of management accounting. The paper carries important practical implications and also provides an explanation about the detailed process of institutionalisation of the BSC in the case study firm, which would offer learning points for practicing managers of other firms in successfully implementing and institutionalising BSC and other management tools.

The rest of the paper is structured as follows. The next section reviews BSC literature; the two sections to follow present the research context and the theoretical framework based on institutional theory, respectively. Research methodology is explained in the next section followed by findings as well as a discussion of findings. The paper concludes with implications of the findings.

\section{Review of Current Literature}

\section{Evolution and Adoption of the Balanced Scorecard}

Following the limitations of traditional management accounting tools and their mismatch to today's competitive markets (Johnson \& Kaplan, 1987), during the last few decades, new accounting tools, such as the BSC have been developed (Kaplan \& Norton, 1992, 1993, 1996). The BSC comprises four perspectives spanning financials and non-financials. It strives to ensure a balance between short term and long term objectives, financial and non-financial measures, lagging and leading indicators, and internal and external perspectives (Kaplan \& Norton, 1996). Since its inception, the BSC has evolved from an improved performance measurement tool in 1992 to a 
strategic management system in 1996, strategy focused organisation in 2001, strategy map in 2004 and as a tool for corporate-wide strategic alignment in 2006 (Dechow, 2012). Ax and Bjornenak (2005) state that bundling of the BSC with other techniques, fashion-setters such as consultancy firms, early adopters and accounting academics have led to its diffusion in Sweden. Firms may adopt BSC due to different motives, such as to translate strategy into action, manage organisational change, implement quality programmes and win awards for excellence in quality; due to managerial fads and fashions; and as a means to abandon traditional budgetary control (Malmi, 2001).

\section{Benefits, Criticisms, Successes and Failures of the Balanced Scorecard}

Over the years there has been a stream of BSC research, and it has been subjected to praise as well as to criticism. While Malina, and Selto (2001) suggest that BSC is an effective tool for communicating strategy, the survey study of Hoque and James (2000) revealed that organisational performance improved with the use of BSC. This is because it leads to focusing on a handful of strategically relevant measures in a single report, making cause-and-effect relations transparent and avoiding suboptimisation. Researchers have noted that a positive relationship exists between size and BSC usage (Bourne, Kennerley, \& Franco, 2005; Hoque \& James 2000) where, for example, larger the firm size, the more practical it is to use the BSC. Madsen and Stenheim (2015) note that the interpretation and use of BSC varies across scholars and practitioners, and due to the interpretive and practice variations, different organisations have implemented it to achieve different purposes, such as to improve performance, improve strategic management, assist managers to focus on strategy, structure and vision, as well as to understand and guide strategy implementation.

Particularly in the telecommunications sector, the application of BSC in performance measurement at Telkom Kenya has been explored. The study revealed that the company primarily uses the BSC for strategy implementation and as a performance measurement tool (Nzuve \& Nyaega, 2013). Further Othman et al. (2018) report on a BSC implementation in a Malaysian telecommunications company. The findings highlight problems and weaknesses of the BSC, and show that its implementation has far reaching consequences for an organisation, and that managers need to alter their organisation's internal conditions to enable the implementation.

Notwithstanding its merits, the BSC has been subjected to criticisms as well, particularly relating to the causality of linkages (Nørreklit, 2000). Furthermore, Neely (2005) claims that the failure of the BSC to consider more dimensions, such as competition, human resources (HR), suppliers, product/service quality, and 
environment/community, limits the comprehensiveness of the model. BSC has also been criticised due to its biasness towards financial measures in performance evaluation (Lipe \& Salterio, 2000). Moreover, Madsen and Stenheim (2015) have identify six criticisms of the BSC: (1) causal relationships across the perspectives and measures; (2) assumption that organisations implement strategy as a rationale topdown process; (3) use of dramatic and seductive rhetoric in the BSC literature; (4) hindering creativity, innovation and organisational learning; (5) BSC as a management trend/fashion; and (6) BSC as a consultants' product as 'old wine in new bottles'.

It is further claimed that the BSC influences the culture of an organisation, and that the implementation of the BSC may require substantial changes in the culture within an organisation, to gain top management support and commitment from employees (Madsen \& Stenheim, 2015). Besides, in their study Andon et al. (2005) focusing on balance, strategic alignment, and cause-and-effect relations noted that the practice of BSC is diverse and that making it work is problematic. In a similar vein, Wickramasinghe et al. (2008) revealed, based on a Sri Lankan case study, how the BSC became vulnerable to operational failures and design faults. Lack of top management commitment, delegation of the project to middle management and lack of alignment to strategy are common causes of BSC failures (Schneiderman, 1999). Paranjape, Rossiter, and Pantano (2006) identified the implementation of BSC to be operationally difficult. Khan and Sartorius (2011) stated that BSC adopting companies used it either in a limited manner or in an incomplete version, while Chavan (2009) explored how managers' cognitive limitations have prevented an organisation from benefiting from BSC information. Against the backdrop of only a few BSC success stories despite its claimed merits, further insights into how a BSC can be successfully implemented and sustained will be of interest to researchers and to practitioners. This is the focus of this paper.

\section{Research Context}

This research is based on a case study of Telinotec, a leading player in the highly competitive telecommunications industry of Sri Lanka. It is a world-class telecommunications operator that provides an array of value added high-speed broadband and voice services to businesses and residential customers in Sri Lanka. It is one of the largest fixed line operators in the country with a subscriber base in excess of 1.2 million, and has over 60 own branch offices along with over 600 retail outlets 
island-wide (Telinotec, 2016). The firm is staffed by a committed team of professionals with international exposure and local knowledge, and cutting edge technology. See Appendix 1 for its organisational chart. Due to the stiff competition in the industry, Telinotec is faced with severe costs and profit pressures and it is highly focused on its performance. Consequently, it has adopted various new technologies and innovative management tools (including the BSC) to boost its performance (Telinotec, 2016). More importantly, Telinotec is a suitable context for this paper as BSC has been successfully implemented and sustained in the firm through improvements made over a period nearing two decades, and this paper sheds light on how this success was achieved.

\section{Theoretical Framework}

This paper is founded upon the theoretical underpinning of institutional theory, more specifically the institutionalisation model of Tolbert and Zucker (1996). Institutionalisation refers to the process through which individual actors transmit what is socially defined as real (Zucker, 1987), and the components of a formal structure become widely accepted as appropriate (Tolbert \& Zucker, 1983). Thus institutionalisation occurs whenever there is reciprocal typification of habitual actions (Berger \& Luckman, 1967). Building upon Berger and Luckman (1967), Tolbert and Zucker (1996) introduced an institutionalisation model, which consists of three stages (pre-institutional, semi-institutional and full-institutionalisation) characterised by three sequential processes (habitualisation, objectification and sedimentation). Table 1 presents a summary of these stages.

\section{Habitualisation}

Berger and Luckman (1967) stated that any action that is repeated frequently gets casted into a pattern, and these processes can be considered as being at the preinstitutionalisation stage. Technological change, market forces and legislation may prompt innovations at this stage (Tolbert \& Zucker, 1996). However, the level of theorising about the proposed new structures are at the initial stage of the institutionalisation process, and the methods through which solutions are found vary due to the diversity of the approaches adopted by individual agents. The failure rate of institutionalisation is high at this stage. Organisations encountering a problem may, as part of their search for solutions, also consider solutions of others (DiMaggio \& Powell, 1983). Although imitation may follow, there is little consensus on the general utility of the innovation. 
Table 1: Institutionalisation Process (Tolbert \& Zucker, 1996)

\begin{tabular}{lll}
\hline Stage & \multicolumn{1}{c}{ Process } & \multicolumn{1}{c}{ Description } \\
\hline $\begin{array}{l}\text { Pre- } \\
\text { institutional }\end{array}$ & Habitualisation & $\begin{array}{l}\text { Innovations and changes done due to specific } \\
\text { organisational problems, resulting in structures at } \\
\text { the pre-institutionalisation stage. This may take } \\
\text { into account solutions adopted in other firms } \\
\text { (mimetic). }\end{array}$ \\
$\begin{array}{l}\text { Semi- } \\
\text { institutional }\end{array}$ & $\begin{array}{l}\text { Objectification } \\
\text { Development of social consensus between } \\
\text { decision makers in the organisation on the value } \\
\text { of the structure by obtaining and analysing } \\
\text { information on its dissemination in other } \\
\text { organisations in the same field (inter- } \\
\text { organisational monitoring). Leaders are viewed } \\
\text { as defenders of change, and this is attributed to } \\
\text { general cognitive and normative legitimacy. }\end{array}$ \\
$\begin{array}{l}\text { Full- } \\
\text { institutionalisation }\end{array}$ & Sedimentation & $\begin{array}{l}\text { Complete propagation of structures for a long } \\
\text { period of time. }\end{array}$
\end{tabular}

\section{Objectification}

The semi-institutionalisation stage is characterised by the objectification of the new institutional element, i.e. the element becomes wide-spread and permanent within the organisation (Tolbert \& Zucker, 1996). Objectification occurs because organisations in this phase are making use of information, based on the results of implementation experiences in other organisations. This is done through monitoring competing organisations and by working towards increasing its competencies relative to competitors by internally monitoring the results of the new structures. Structures that undergo the objectification process become well distributed. The new element that is being institutionalised in the organisation at this stage (semi-institutional) is primarily distributed through normatisation, which permits many new adopters to access the new element (irrespective of their initial beliefs). During this stage, the leaders (defenders of change) play a vital role theorising it, to attribute general cognitive and normative legitimacy.

\section{Sedimentation}

Total institutionalisation occurs through the continued use, maintenance, and survival of the structure over successive generations of organisational members, which is sedimentation. This is featured both by the virtually complete diffusion of structures across the group of actors theorised as appropriate adopters, and by the 
perpetuation of structures over a long time period. The experiences thus become readily transmittable. Tolbert and Zucker (1996, p.184) state, "identification of factors that affect the extent of diffusion and long-term retention of this structure are therefore important in understanding the process of sedimentation." Creating a new structure requires considerable effort, including managing resistance.

In recent years there has been an expansion in institutional theory bent management accounting research (Cruz, Major, \& Scapens, 2009). From the perspective of institutional theory, management accounting systems are seen to be inextricably linked to the prevailing rules and norms which structure social and organisational life (Burns \& Scapens, 2000), and an institution is less susceptible to interventions if it is embedded in the structure of organisations. Given the relationships between everyday actions and interactions, overtime, rules, routines as well as accounting systems (such as budgets) becomes sedimented and taken-forgranted, and get produced and reproduced within organisations (Burns \& Scapens, 2000). However, all newly introduced rules and routines will not necessarily become institutionalised. If new (management accounting) systems challenge what is prevailing in the organisation, they may not be reproduced, and as a result may fail to become institutionalised and taken-for-granted (Burns \& Scapens, 2000).

Currie and Finnegan (2011) have used Tolbert and Zucker (1996) model in the introduction of a large-scale IT-enabled change in the context of a highly institutionalised environment. They note that habitualised behaviours conspired to resist the adoption of new working practices as it conflicts with existing culturalcognitive views. Pishdad and Haider (2013) apply a stage-based model encompassing the pre-implementation, implementation, and post-implementation stages of ERP assimilation in an integrated structure. Amidst this literature, there is limited research on the institutionalisation of new management accounting techniques (see the activity based costing study by Cardes \& Gooneratne, 2016 for an exception), and this paper focuses on the institutionalisation of the BSC based on Tolbert and Zucker (1996) institutionalisation process.

\section{Research Methodology}

This research adopts the qualitative methodology and single case study approach (Silverman, 2005; Yin, 2011). Qualitative research strives to provide a deep understanding of a phenomenon. Case study is an empirical inquiry that probes into a contemporary phenomenon within the real-life context, particularly when the boundaries between the phenomenon and the context are not clearly evident (Yin, 
2011). This approach is thus, capable of providing an in-depth inquiry into the issues explored, such as to understand the reasons for the use of specific accounting practices in a firm, rather than to produce generalisations (Scapens, 1990). Using the case study research strategy, this paper strives to explore the research question, how has the case firm implemented and institutionalised the BSC as an organisational practice using field data from a firm in the telecommunications industry of Sri Lanka.

\section{Data Collection}

In qualitative case studies, multiple sources can be used for data collection (Yin, 2011). Similarly, this paper triangulates data obtained from different sources, such as in-depth interviews with managers of different departments and review of documentation.

Initially a pilot study was conducted through interviews with the General Manager - HR and Senior Manager - HR to identify the key features of the BSC system in Telinotec. The pilot study revealed that the BSC has been institutionalised as a useful practice in the firm. Accordingly, during the main study, ten interviews were carried out with key actors involved in BSC, focusing on how it has become an institutionalised practice. Interviewees were selected based on purposive sampling to capture the key informants, and each interview lasted for 15-45 minutes. There was much difficulty in establishing contact and gaining appointments for interviews as these managers were very busy and operate under tight time constraints. However, during the interview sessions they provided valuable insights related to the BSC (based on their past and present positions in the firm). The interviews were voice recorded using a suitable device, after obtaining permission from Senior Manager$\mathrm{HR}$, and oral permission was also obtained from each interviewee before recording. A list of interviewees is presented in Table 2 and the interview questions are shown in Appendix 2.

While the theoretical framework was used in formulating interview questions, we were also mindful of exploring new issues emerging from the field.

\section{Ensuring Quality}

To ensure the quality of the study, a number of steps were followed. In terms of data collection methods, interview data were supplemented by data obtained through press releases, annual reports, minutes of meetings, BSC manuals, policies and procedures, training manuals and the website of the case organisation. Such triangulation of evidence gathered from multiple sources increased the credibility of 
findings. Respondent validation (Yin, 2011), where feedback is obtained from interviewees regarding the findings was also employed to reduce the misinterpretation of interview data and to strengthen credibility. Other strategies adopted to enhance quality include, prolonged engagement in the field (during interviewing and documentary reviewing) and building rapport and trust with interviewees to obtain their honest views.

Table 2: Interviewee Details

\begin{tabular}{|c|c|c|c|}
\hline Current Position & Previous Position & Department & $\begin{array}{l}\text { Interview } \\
\text { Duration (In } \\
\text { Minutes) }\end{array}$ \\
\hline General Manager- HR & $\begin{array}{l}\text { Business Development } \\
\text { Manager }\end{array}$ & HR & 60 \\
\hline Senior Manager -HR & HR Manager & HR & 45 \\
\hline HR Executive & HR Executive & HR & 10 \\
\hline Finance Manager & $\begin{array}{l}\text { Assistant Finance } \\
\text { Manager }\end{array}$ & Finance & 30 \\
\hline $\begin{array}{l}\text { Revenue Assurance } \\
\text { Manager }\end{array}$ & $\begin{array}{l}\text { Revenue Assurance } \\
\text { Manager }\end{array}$ & Finance & 10 \\
\hline $\begin{array}{l}\text { Senior Customer } \\
\text { Relationship Manager }\end{array}$ & $\begin{array}{l}\text { Customer Relationship } \\
\text { Manager }\end{array}$ & Sales & 45 \\
\hline $\begin{array}{l}\text { Account Manager } \\
\text { Enterprise Solutions }\end{array}$ & Sales Assistant Manager & Sales & 10 \\
\hline Senior Manager- IT & IT Manager & IT & 30 \\
\hline $\begin{array}{l}\text { IT Operations } \\
\text { Manager }\end{array}$ & Operational Manager & IT & 15 \\
\hline $\begin{array}{l}\text { General Manager } \\
\text { Technical }\end{array}$ & $\begin{array}{l}\text { General Manager } \\
\text { Technical }\end{array}$ & Technical & 20 \\
\hline
\end{tabular}

\section{Making Sense of Data}

The voice recorded interviews were transcribed verbatim before making sense of such data. Categories and themes were identified with reference to the initial implementation of the BSC (from 2000-2012), subsequent developments to it (after 2012), and its institutionalisation in the firm as a useful practice, following through 
habitualisation, objectification and sedimentation guided by the theoretical framework related to the institutionalisation process of Tolbert and Zucker (1996) as shown in Table 3.

Thereafter, data was coded manually.

Table 3: Themes and Categories

\begin{tabular}{ll}
\hline Theoretical notion & Themes /categories \\
\hline Pre-institutional (Habitualisation) & Legitimacy \\
& Mimic isomorphism \\
& Consultants \\
Semi-institutional (Objectification) & Link to individual performance \\
& Periodic review \\
& Training and workshops \\
& Employee acceptance \\
& Normative isomorphism \\
& Review meetings \\
Full- institutionalisation & Continued training \\
(Sedimentation) & Rules and routines \\
& Day-to-day activities \\
& Integration to operational practices \\
\hline
\end{tabular}

\section{Findings and Discussion}

This section presents the findings of the paper in terms of the BSC system of Telinotec from 2000-2012, after 2012 and how the institutionalisation of BSC has taken effect moving through the sequential stages of pre-institutional: Habitualisation, semi-institutional: Objectification, and full institutionalisation: Sedimentation in line with the model of Tolbert and Zucker (1996).

\section{Balanced Scorecard of Telinotec from 2000-2012}

The BSC of Telinotec originated from the interest of the then Business Development Manager (presently General Manager - HR) who was inspired to implement new techniques in light of the competition in the industry, to create a 'modern' image and to gain legitimacy. Following this interest, the BSC was introduced to the firm, facilitated by consultants in year 2000. The decision to implement the BSC was thus linked to management fads and fashion (Abrahamson, 1996; Malmi, 2001; Ax \& Bjornenak, 2005; Modell, 2009), to show that the firm is following the latest practices of leading companies (DiMaggio \& Powell, 1983). 
Telinotec's BSC was an off-the-shelf system, which measured performance via the typical four perspectives, namely financial, customer, internal business processes, and learning and growth (Kaplan \& Norton, 1996). See Table 4 for the perspectives and measures.

Table 4: Perspectives and Measures of the BSC (From 2000-2012)

\begin{tabular}{|c|c|}
\hline Perspectives & Measures \\
\hline Financial & $\begin{array}{ll}\text { - } & \text { Profitability } \\
\text { - } & \text { Return on investment } \\
\text { - } & \text { Revenue growth }\end{array}$ \\
\hline Customer & $\begin{array}{ll}\text { - } & \text { Customer satisfaction } \\
\text { - } & \text { Retention } \\
\text { - } & \text { Market share }\end{array}$ \\
\hline Internal business processes & $\begin{array}{ll}\text { - } & \text { Quality } \\
\text { - } & \text { Response time } \\
\text { - } & \text { Cost }\end{array}$ \\
\hline Learning and growth & $\begin{array}{ll}\text { - } & \text { Employee satisfaction } \\
\text { - } & \text { Information system availability } \\
\text { - } & \text { Revenue per employee }\end{array}$ \\
\hline
\end{tabular}

At this stage, the BSC project was rather preliminary, and not well integrated to the firm's activities. It was basically an incentive and increment system; where half yearly employees were given BSC targets and evaluated based on the individual, departmental and company objectives. There was no periodic review linked to the BSC, and it was evident through document review that KPIs were not monitored (for instance, monthly). Nevertheless, the BSC during this era helped the firm to improve performance and company image, as apparent from the following quote by the Deputy Managing Director as published in a local newspaper;

Good results in the first half of 2004/05, achieved despite challenges from competitors, we have once again proved the capability of Telinotec's employees and their commitment to achieving company goals. The major contributing factors include our BSC performance measurement system, ongoing staff training and good financial management.

The key benefit of the BSC is overcoming inadequacies of traditional financialbased performance measurement by bringing together financial and non-financial indicators (Kaplan \& Norton, 1992). The early BSC of Telinotec was successful in 
enabling such a balanced approach to performance as revealed through the words of a manager who explained how the BSC was initially used in the firm. He noted, "we use the BSC as a key tool to measure departmental, individual and organisational performance. BSC capture four key perspectives, quantitative and qualitative". He however continued stating;

BSC model is a hierarchical top-down model and it was not easily rooted in the organisation. Not everyone liked it. This was a problem in Telinotec. The project needs to be rooted in the organisation if it is to be successful.

As the above quote suggests, despite its usefulness, the BSC of Telinotec had limitations. That is, it did not get the acceptance of all employees, and there was no clear alignment of the BSC with strategy (Kaplan \& Norton, 1996). Therefore, in its initial form, the BSC was of limited use as a strategic management accounting tool. This era represents the pre-institutional stage: habitualisation in the institutionalisation of the BSC.

\section{Pre-institutional Stage: Habitualisation}

Habitualisation encompasses the innovations and changes made in response to particular organisational problems in structures and can be termed as being at the preinstitutional stage. This corresponds to the introduction of BSC (2000-2012), where Telinotec took into account the solutions in other organisations (mimetic), and adopted practices (such as BSC) facilitated by consultants.

Various forces, such as competitors and customer demands for better telecommunication services became important in legitimating the BSC at the preinstitutional stage. The General Manager - HR explained: "based on the business climate targets might get adjusted. Particularly in a competitive industry like this we have to drive our organisation from the top. By using tools like BSC we can do that". At the pre-institutionalised stage it is important to see whether the vision for the BSC would confront existing institutionalised processes and norms, and to what extent it is acceptable in the eyes of employees. Some existing behaviours and actions may hamper the adoption and diffusion of the BSC across the firm. For instance, the IT Operations Manager stated "big changes are there, but people have not been well trained. It is more complicated, so our subordinates are not happy".

Creating acceptance about the BSC in the minds of other organisational members is vital in the transition from the pre-institutionalised stage of habitualisation to semi- 
institutional stage of objectification. This concern was addressed through the subsequent improvements in the BSC, as elaborated next.

\section{Balanced Scorecard of Telinotec from 2012 Onwards}

Improvements to the BSC were initiated from 2012 onwards, after the current Managing Director assumed office. Accordingly, in light of the specific needs of the complex technology led, competitive business environment in which it operates, Telinotec's BSC was linked to individual performance evaluation and to corporate strategy. The BSC during this phase thus covered employee evaluation as well as employee development, i.e. the employees' contribution towards company objectives as well as to his/her own development (see Table 5).

Table 5: Perspectives and Measures of the BSC (2012 Onwards)

\begin{tabular}{|c|c|}
\hline Perspectives & Measures \\
\hline Financial & $\begin{array}{l}\text { - } \quad \text { Increased profits } \\
\text { - } \quad \text { Revenue growth \& mix } \\
\text { - } \quad \text { Cost containment/ reduction/ efficiency }\end{array}$ \\
\hline Customer & $\begin{array}{ll}\text { - } & \text { Customer mobilisation } \\
\text { - } & \text { Customer retention } \\
\text { - } & \text { Customer profitability } \\
\text { - } & \text { Market share } \\
\text { - } & \text { Differentiation in the market }\end{array}$ \\
\hline $\begin{array}{l}\text { Internal Business System \& } \\
\text { Processes }\end{array}$ & $\begin{array}{ll}\text { - } & \text { Efficiency } \\
\text { - } & \text { Effectiveness } \\
\text { - } & \text { Productivity and quality }\end{array}$ \\
\hline Learning and Growth & $\begin{array}{l}\text { - Employee development } \\
\text { - Employee satisfaction } \\
\text { - Employee retention } \\
\text { - Employee productivity }\end{array}$ \\
\hline
\end{tabular}

The Senior Manager - HR explained the revisions that took place after 2012: In the BSC before 2012, we had an evaluation system every six months. Employees were given targets based on the work they do and an evaluation was done, but the BSC was very basic. Now we apply this model in the four perspectives financial, customer, internal and learning and growth by coupling with the evaluation and employee development processes. Employees' key results are defined based on department's key result areas, and department's key result areas are defined based 
on company's KPI. BSC starts with company objectives and is linked to strategy. BSC is evaluated continuously, on a monthly basis by each department. HR gets records every six months. Based on the ratings the development activities and reward systems are planned.

The strategic orientation of the BSC was very much evident in the post- 2012 BSC. Having vast knowledge on the BSC and being a key person behind the changes done in 2012, the General Manager -HR stated:

I worked in a leading Bank for 25 years. In that Bank, I introduced the BSC, it was very successful. BSC is a powerful strategic management tool which makes vision and mission happen. BSC is a revolutionary tool. In our company the revised BSC is well aligned with strategy and helps for performance evaluation.

He continued;

Company's BSC is CEO's BSC. Initially we did a strategic planning workshop in 2012; we created the company's (CEO) BSC where all the KPIs of the four quadrants are initiated with senior people's agreement. That was driven by the CEO. From there every department is given scorecards from $1^{\text {st }}$ April to $31^{\text {st }}$ March each year. From department scorecard every individual is given a scorecard, which is the cascading effect. What I believe is what gets measured get done, what doesn't get measured never gets done. We have to a create measurement managed organisation with performance accountability. Every KPI must be measurable. Based on SMART principle we set the KPIs. KPIs must be pre-agreed whether it's company, department or individual. Then we have to assign weightage to each quadrant; financial $30 \%$, customer $30 \%$, internal process $20 \%$ and learning growth $20 \%$.

It is thus evident that Telinotec's top management has used their knowledge to improve the BSC and to ensure that there is a match between the BSC and the firm's needs. For instance, the Revenue Assurance Manager stated that through his Chartered Institute of Management Accountants (CIMA) studies he gained knowledge on BSC and used such knowledge to craft the BSC as suitable to the firm. He added;

BSC depends on the company. For Telinotec it is suitable to adapt the BSC as four perspectives, it is realistic; the key areas focus on these perspective, and based on our strategies our company's BSC covers those.

Suggesting the influence of normative isomorphic forces (DiMaggio \& Powell, 1983), some managers of the finance department stated that being CIMA members, the knowledge they have gained on BSC have helped in initiating improvements to the BSC. 
Kaplan and Norton (1996) have identified acceptance and participation by the senior management as a key reason for BSC success. Similarly, positive attitudes and support of top managers of Telinotec have led it to be derived from the organisation's strategy and to be a success. Translating strategy into action is a central argument promoting the BSC (Kaplan \& Norton, 1996). This is evident in Telinotec. The alignment between strategy and the BSC has also helped in performance evaluation. The Customer Relationship Manager stated;

In 2012 the BSC was transferred to individual evaluation. All departments were involved in BSC implementation, because if there is a change it should be right across the entire organisation. BSC was implemented by HR to all the departments. All top, middle and operational level employees should get involved. So initially internal training about BSC was given to employees. Rewards are based on BSC. $B S C$ is transparent in our company. It is successful because we effectively measure performance. We disciplined the employees into a systematic process.

Several other interviewees too explained that the BSC of the company is cascaded to the individual level, where each employee is communicated about the appraisals and are thus aware of the measures.

To integrate the BSC and strategies, Kaplan and Norton (2004) introduced the strategy map. In 2012, Telinotec's BSC team also developed a performance measurement cause-and-effect matrix and a strategy map based on the four perspectives of the BSC. In this process, the HR department played a major role: they developed a BSC manual and uploaded it to the system. This serves as a guide for executives to implement and practice the BSC in their division starting from developing the strategy map to the cascading process.

At the early years of the BSC, Telinotec encountered negative attitudes from certain managers who mobilised their interests against this new device. To manage these negativities, the HR department obtained opinions from various managers and got them involved in the process. Workshops and training sessions were held in each department together with monthly evaluations done through online questionnaires for all employees. As the communication of the scorecard to employees is vital (Kaplan \& Norton, 1996), and managers' cognitive limitations prevent an organisation from benefiting from BSC information (Chavan, 2009), Telinotec ensured two-way communication of the BSC between and within different levels of the firm, to reduce misunderstandings, while enabling employees to have a complete picture of how their work contributes to the business. Such endeavours were significant in the semiinstitutional stage / objectification. 


\section{Semi-institutional Stage: Objectification}

Objectification is a significant component of the institutionalisation process, which occurs alongside the diffusion of structure. Improvements done to the BSC and thereby the creation of a social consensus on the value of the tool is significant at this stage. This also involves communicating the value of the structure/tool (such as the BSC) by continuous awareness sessions as well as by obtaining and analysing relevant information and disseminating them to others.

The new BSC format which addressed lapses in the initial BSC as well as the roots to employee dissatisfaction is significant during objectification. Senior managers of all the departments represent the BSC team, and are involved in BSC decisions. In the management review meeting managers give suggestions, while participating in forums to discuss the strength and weaknesses of the BSC. Conducting training programmes / workshops for managers and low level employees, making employees aware of how evaluations are done and senior managers communicating outcomes of BSC review meetings to their department employees are significant at this stage.

Objectification and diffusion of the BSC in Telinotec is being spearheaded by a number of individuals. As a key person engaged in the task, the General Manager HR stated;

Every month we have monthly review meetings and we display the department and company BSC on the big screen. All the senior managers are participating and discussing the strengths and weaknesses. Employee resistance is low. We gave time to understand the concept. We conducted training and workshops for managers and low level employees. Employees have freedom to discuss their views related to KPIs. Target settings are done in one to one meetings. Every month target setting, development plans have to be discussed in each department.

The Senior HR Manager explained the changes;

The new BSC is initiated by HR department. Initially people were not ready to change. But all are involved in BSC implementation now. Senior managers of all the departments are representing the BSC team. They communicate to their department employees. Workshops and trainings were organised. BSC focuses on setting targets in advance, and it is evaluated continuously, monthly basis by each department. HR gets records every six months. Based on the ratings, development activities and reward systems are planned. When immediate supervisors evaluate their employees they use employee feedback forms and development forms. Superior and subordinates discuss and send to HR. 
Account Manager - Enterprise Solution noted that "BSC had now been developed to cope up with the business. HR communicated the changes. Proper guidance is given to the employees and communicated department-wise." General Manager Technical added:

BSC changes were initiated by HR department. All the departments' comments are taken when BSC was implemented. We have a BSC for whole company cascaded to individuals. Each employee is communicated about the appraisals. So employees are aware of their measures.

The Customer Relationship Manager stated how improvements were done overtime. He added;

Time to time the BSC got changed, based on divisions' requirements, core-activities, internal areas and handling customers. These changes are communicated through emails. Meetings are conducted with divisional heads and divisional secretaries. In the meeting HR department present the changes, and then the heads are responsible to communicate with the employees in each department. Recently we had a change they decided more percentage to internal perspectives. Then I communicated with my department staff to do relevant changes.

On a similar note the Senior IT Manager elaborated;

The reviews are communicated to the employees. Employees can comment in the final review meeting. Comments are discussed. Employees are aware how the evaluations are done, implementation guidance workshops are held. Freedom to decide these is given to the departments.

As the General Manager - HR stated, managers had to present their departments' BSC in monthly review meetings, and at these face to face evaluations, negotiations and compromises were common.

Through these initiatives Telinotec has been able to obtain employee support towards the BSC, and this has led to further adoption and diffusion to follow. Objectification occurs when the drive for diffusion shifts from simple initiation to a more normative base (Tolbert \& Zucker, 1996) as witnessed in the post 2012 BSC of Telinotec. Structures that are being objectified through further diffusion are termed as being at the stage of semi-institutionalisation.

\section{Full-institutionalisation: Sedimentation of the Balanced Scorecard}

Since its introduction to the firm in 2000 , and following the improvements made after 2012, Telinotec's BSC has become an institutionalised practice, a concept noted 
by Tolbert and Zucker (1996). During the early introduction of the BSC, the mimetic processes that resulted in the adoption of new structures correspond to habitualisation. Recognising factors that affect the diffusion in the long-term and taking suitable measures, such as accommodating the views of managers by the change leaders through training programmes, workshops, meetings and emails, as well as improvements by way of linking the BSC to strategy and individual performance evaluations leads to objectification.

Sedimentation is where structures are reproduced and become taken-for-granted, through nearly complete diffusion of structures within a group of actors and by the reinforcement of structures across a long period of time. This is currently evident with Telinotec's BSC, with the BSC being diffused through continuous dialogue and review, as well as through training programmes, while being aligned with strategy. After believing in the practice of BSC, it is now being routinely carried out in all departments. The Revenue Assurance Manager added:

As subordinates have freedom to communicate about the BSC, if anything is missed or does not satisfy them with regard to the evaluation, they have freedom to discuss with their supervisor. So BSC is effective. If you don't identify KPIs properly then the whole exercise is not effective. KPIs should be revised frequently. It should be flexible. In Telinotec it is suitable to adapt the BSC.

Most of the interviewees accepted that BSC is a useful tool. The Finance Manager noted:

Training sessions are given for each department, workshops on BSC are held, and people are selected to participate. Monthly reviews of performance are done; six month reviews are done for all departments. Updated BSC is communicated to all the department heads. So in Telinotec the BSC is an effective tool to measure performance.

Senior Manager - HR explained the present status of the BSC as:

The KPI targets are set annually. Monthly reviews are done individually and department-wise. Employees have the freedom to discuss. We have open door policy communication. In our company the BSC is aligned with strategy and help in performance evaluation. We continue the BSC because of the benefits of the tool.

The BSC principles were incorporated into Telinotec's procedural guidelines, translated in terms of rules and routines, and absorbed to the day-to-day activities of the firm. The General Manager - HR stated;

The BSC updates are communicated through emails frequently. All heads are participating in BSC decisions. BSC monthly review meetings are held. We believed 
in it and made it user friendly. We have explained what is this BSC, how it work, what are the end results. Some of the heads used to focus on their work and neglect this. To overcome that problem we have monthly review meeting. All heads have to prepare the BSC before the meeting.

According to interview data, Telinotec's BSC is integrated into managerial and operational practices, and is widely accepted across the firm, as an effective performance measurement tool, which facilitates other systems of the firm. IT Operations Manager stated;

The company maintains ISO standards. It is going to get another certificate. For that the company has to improve the BSC to help to maintain quality standards.

The General Manager - HR further elaborated on the future plan of Telinotec; We follow ISO quality standards. Our main aim is integrating people to business. BSC has done that. Long time ago customers were well accepted when we are in CDMA. Now we are moving with new technology $4 G H$, to cope up with these we are implementing different strategies and BSC has helped.

The industry in which Telinotec operates is increasingly getting competitive. In this scenario, BSC has been useful for all aspects of the business, such as profitability, sales volume, customer satisfaction, systems and processes, developing people, innovation, which are captured through KPIs of the BSC. Therefore, interviewees accepted BSC to be an enabling tool which is institutionalised in Telinotec.

Institutionalisation of new practices involves the formation of new structures, processes, and roles that subsequently become routinized and formalised practices, which are embedded in the organisational fabric across a long period of time (Zucker, 1987). Benefits of a performance measurement innovation may be achieved only after lengthy and iterative periods and substantial efforts may be needed to make an innovation work (Andon et al., 2005). Similarly, amidst improvements to the initial scorecard, from 2012 onwards, as well as the support from the top management and the buy-in from employees at all levels, Telinotec's BSC has become integrated to the day-to-day activities of the firm and has got sustained as an institutionalised practice over a period nearing two decades. The BSC is now routinely carried out while being continued due to the benefits realised.

\section{Conclusion}

The BSC implementation in Telinotec is a success story; several points are noteworthy in this regard. The BSC has been embedded to the company's day-to-day 
managerial and operational practices and everyday work of managers, hence institutionalised as a useful practice in the case firm. With the implementation of the $\mathrm{BSC}$, the performance monitoring of Telinotec has become balanced, in terms of the integration between non-financial and financial performance measures as well as long-term and short-term financial performance (Kaplan \& Norton, 1996). Managers and employees at all levels supported and were committed towards the BSC, for it enabled them to obtain a complete picture of how their work contributes to business success. More importantly, the BSC was linked to the employee incentive system. It was commonly accepted in the firm that the BSC and performance measurements based on the four perspectives are appropriate for Telinotec, as the company operates in a competitive service industry with a profit motive.

This paper makes several contributions. Through rich empirical evidence on institutionalisation of the BSC, in terms of how the idea to adopt it was initiated, translated into practice and eventually institutionalised, the paper advances knowledge on the institutionalisation of management accounting initiatives, such as BSC. From a theoretical point of view, the paper extends the use of the institutionalisation model of Tolbert and Zucker (1996) to the area of management accounting, and this forms a theoretical contribution of the paper. This model although deemed appropriate, has rarely been used in exploring institutionalisation of management accounting tools. The paper is also of significance to practitioners. It provides an explanation to the institutionalisation process of BSC in the case organisation taking into consideration its particular context, and offers useful insights to practicing managers on how management accounting tools, such as the BSC can be made successful by continuously altering and modifying to keep up with the expectations of managers and by integrating it to the day to day activities of the firm.

\section{Declaration of Conflicting Interests}

The authors declared no potential conflicts of interest with respect to the research, authorship, and publication of this article.

\section{References}

Abrahamson, E. (1996). Management fashion. Academy of Management Review, 21(1), 254-285. doi: 10.2307/258636

Ahn, H. (2001). Applying the Balanced Scorecard concept: An experience report. Long Range Planning, 34(4), 441-461. doi: 10.1016/S0024-6301(01)00057-7

Andon, P., Baxter, J., \& Mahama, H. (2005). The Balanced Scorecard: Slogans, seduction, and state of play. Australian Accounting Review, 15 (1), 29-38. doi: 10.1111/j.1835-2561.2005.tb00249 
Ax, C., \& Bjornenak, T. (2005). Bundling and diffusion of management accounting innovations: The case of the Balanced Scorecard in Sweden. Management Accounting Research, 16(1), 1-20. doi: 10.1016/j.mar.2004.12.002

Berger, P., \& Luckmann, T. (1967). Society as objective reality. In Berger, P., \& Luckmann, T. (Eds.), Social construction of reality (pp. 63-134). New York: Anchor Books.

Bourne, M., Kennerley, M., \& Franco, M. (2005). Managing through measures: A study of impact on performance, Journal of Manufacturing Technology Management, 16(4), 373-395. doi: 10.1108/17410380510594480

Burns, J., \& Scapens, R.W. (2000). Conceptualizing management accounting change: An institutional framework. Management Accounting Research, 11(1), 3-25. doi: 10.1006/mare.1999.0119

Butler, A., Letza, S. R., \& Neale, B. (1997). Linking the Balanced Scorecard to strategy. Long Range Planning, 30(2), 242-253. doi: 10.1016/S00246301(96)00116-1

Cardes, S., \& Gooneratne, T. N. (2016). Institutionalization of Activity Based Costing in a Sri Lankan manufacturing firm: A case study. Colombo Business Journal, $7(1), 37-51$.

Chavan, M. (2009). The Balanced Scorecard: A new challenge. Journal of Management Development, 28(5), 393-406. doi: 10.1108/02621710910955930

Cruz, I., Major, M., \& Scapens, R. W. (2009). Institutionalization and practice variation in the management control of a global/local setting. Accounting, Auditing \& Accountability Journal, 22(1), 91-117. doi: 10.1108/09513570910923024

Currie, W. L., \& Finnegan, D. J. (2011). The policy practice nexus of electronic health records adoption in the UK NHS: An institutional analysis. Journal of Enterprise Information Management, 24(2), 146-170. doi: 10.1108/17410391111106284

Davis, S., \& Albright, T. (2004). An investigation of the effect of Balanced Scorecard implementation on financial performance. Management Accounting Research, 15(2), 135-153. doi: 10.1016/j.mar.2003.11.001

Dechow, N. (2012). The Balanced Scorecard: Subjects, concept and objects - A commentary. Journal of Accounting \& Organizational Change, 8(4), 511-527. doi: 10.1108/18325911211273509

DiMaggio, P. J., \& Powell, W. W. (1983). The iron cage revisited: Institutional isomorphism and collective rationality in organizational fields. American Sociological Review, 48(2), 147-160. doi: 10.2307/2095101

Epstein, M., \& Manzoni, J. F. (1998). Implementing corporate strategy: From Tableaux de Bord to Balanced Scorecards. European Management Journal, 16(2), 190-203. doi: 10.1016/S0263-2373(97)00087-X 
Hoque, Z., \& James, W. (2000). Linking Balanced Scorecard measures to size and market factors: Impact on organizational performance. Journal of Management Accounting Research, 12, 1-17. doi: 10.2308/jmar.2000.12.1.1

Hoque, Z. (2014). 20 years of studies on the balanced scorecard: Trends, accomplishments, gaps and opportunities for future research. The British Accounting Review, 46(1), 33-59. doi: 10.1016/j.bar.2013.10.003

Johnson, H. T., \& Kaplan, R. S. (1987). The rise and fall of management accounting. IEEE Engineering Management Review Management Accounting, 15(3), 36-44. doi: 10.1109/EMR.1987.4306297

Kaplan, R.S., \& Norton, D.P. (1992). The Balanced Scorecard: Measures that drive performance, Harvard Business Review, 70(1), 71-79.

Kaplan, R. S., \& Norton, D. P. (1993). Putting the Balanced Scorecard to Work. Harvard Business Review, September - October, 134 -147.

Kaplan, R.S., \& Norton, D.P. (1996). The Balanced Scorecard: Translating strategy into action. Boston, MA: Harvard Business School Press.

Kaplan, R. S., \& Norton, D. P. (2004). The strategy map: Guide to aligning intangible assets. Strategy \& Leadership, 32(5), 10-17. doi: 10.1108/10878570410699825

Kasurinen, T. (2002). Exploring management accounting change: The case of Balanced Scorecard implementation. Management Accounting Research, 13(3), 323-343. doi: 10.1006/mare.2002.0191

Khan, M. U., \& Sartorius, A. K. (2011). The use of multiple performance measures and the Balanced Scorecard (BSC) in Bangladeshi firms. Journal of Accounting in Emerging Economies, 1(2), 160-190. doi: 10.1108/20421161111138512

Lipe, M., \& Salterio, S. (2000). The Balanced Scorecard: Judgmental effects of common and unique performance measures. Accounting Review, 75 (3), 283-298.

Madsen, D. O., \& Stenheim, T. (2015). The Balanced Scorecard: A review of five research areas. American Journal of Management, 15(2), 24-41.

Malina, M., \& Selto, F. (2001). Communicating and controlling strategy: An empirical study of the effectiveness of the Balanced Scorecard. Journal of Management Accounting Research, 13(1), 47-90. doi: 10.2139/ssrn.278939

Malmi, T. (2001). Balanced scorecards in Finnish companies. Management Accounting Research, 12(2), 207-220. doi: 10.1006/mare.2000.0154

Modell, S. (2009). Bundling management control innovations: A field study of organizational experimenting with total quality management and the balanced scorecard. Accounting, Auditing \& Accountability Journal, 22, 59-90. doi: 10.1108/09513570910923015

Neely, A.D. (2005). The evolution of performance measurement research: Developments in the last decade and a research agenda for the next. International 
Journal of Operations and Production Management, 25(12), 1264-1277. doi: $10.1108 / 01443570510633648$

Norrekilt, H. (2000). The balance on the balanced scorecard: A critical analysis of some of its assumptions. Management Accounting Research, 11, 65-88. doi: 10.1006rmare.1999.0121

Norreklit, H. (2003). The Balanced Scorecard: what is the Score? A rhetorical analysis of the Balanced Scorecard. Accounting, Organizations and Society, 28, 591-619. doi: 10.1016/S0361-3682(02)00097-1

Nzuve, S., \& Nyaega, G. (2013). Application of Balanced Scorecard in performance measurement at Essar Telecom Kenya Limited (March 11, 2013). doi: $10.2139 /$ ssrn. 2231330

Othman, R., Abdullah, N., Zizah, A., Senik, C., Khairy, A., Domil, A., \& Hamzah, N. (2018). A case study of Balanced Scorecard implementation: The hidden problems. Retrieved from https://www.researchgate.net/publication/ 267860788_A_CASE_STUDY_OF_BALANCED_SCORECARD_IMPLEME NTATION_THE_HIDDEN_PROBLEMS

Papalexandris, A., Ioannou, G., \& Prastacos, G. P. (2004). Implementing the Balanced Scorecard in Greece: A software firm's experience. Long Range Planning, 37(4), 351-366. doi: 10.1016/j.lrp.2004.05.002

Paranjape, B., Rossiter, M., \& Pantano, V. (2006). Performance measurement systems: Successes, failures and future - A review. Measuring Business Excellence, 10(3), 4-14. doi: 10.1108/13683040610685748

Pishdad, A., \& Haider, A. (2013). ERP institutionalization: Exploring the influential factors. Journal of Enterprise Information Management, 26(6), 642-660. doi: 10.1108/JEIM-07-2013-0046

Scapens, R. W. (1990). Researching management accounting practice: The role of case study methods. The British Accounting Review,22(3), 259-281. doi: 10.1016/0890-8389(90)90008-6

Schneiderman, A. M. (1999). Why Balanced Scorecards fail. Journal of Strategic Performance Management, Special issue, 6-11.

Silverman, D. (2005). Doing qualitative research: A practical handbook $\left(2^{\text {nd }} e d.\right)$. Thousand Oaks, CA: Sage.

Speckbacher, G., Bischof, J., \& Pfeiffer, T. (2003). A descriptive analysis on the implementation of Balanced Scorecards in German-speaking countries. Management Accounting Research, 14(4), 361-387. doi: 10.1016/j.mar.2003.10.001

Tolbert, P. S., \& Zucker, L. G. (1996). The institutionalization of institutional theory. In S. Clegg, C. Hardy, \& W. Nord (Eds.). The handbook of organization studies (pp. 175-190). London, UK: Sage Publications Ltd. 
Tolbert, P. S., \& Zucker, L. G. (1983). Institutional sources of change in the formal structure of organizations: The diffusion of civil service reform, 1880-1935. Administrative Science, 30, 22-39. doi: 10.2307/2392383

Wickramasinghe, D., Gooneratne, T., \& Jayakody, J. A. S. K. (2008). Interest lost: The rise and fall of Balanced Scorecard project in Sri Lanka. Advances in Public Interest Accounting, 13, 237-271. doi: 10.1016/S1041-7060(07)13009-1

Yin, R. K. (2011). Qualitative research from start to finish. New York: The Guilford press.

Zucker, L.G. (1987). Institutional theories of organization. Annual Review of Sociology, 13(1), 443-464. 


\section{Appendix 1: Telinotec Organisational Chart}

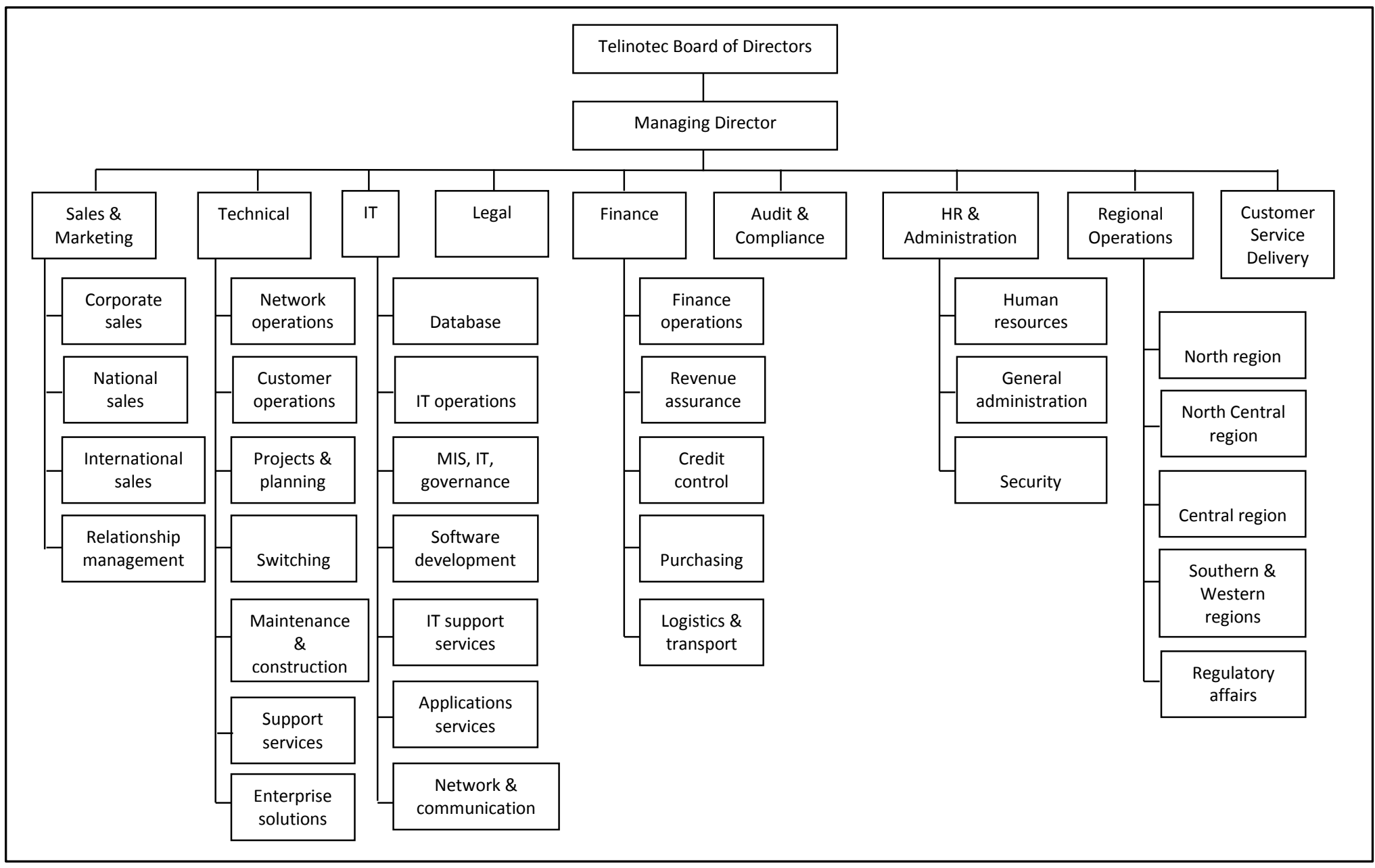




\section{Appendix 2: Interview Questions}

1. What is your position and responsibility area in the organisation?

2. How long have you worked in your current position?

3. How long have you been participating in the implementation of BSC in your organisation?

4. What do you like most about BSC implementation?

5. In your opinion, do you see that BSC added value for your organisation? How?

6. Did the implementation of BSC - Transforms strategy into action and desired behaviours?

7. Briefly explain how your company initiated the BSC?

8. What are the specific organisational problems faced in the initial stage? What are the changes and innovations made to overcome those problems?

9. What kind of employees' attitudes towards change in the organisation?

10. How was managers' commitment to overcome the problems?

11. How your working environment changed after this strategic change?

12. How did you learn about the BSC?

13. How often the key measures and strategy are discussed in the organisation, can everybody see the results?

14. Were any workshops organized with other managers and employees to review the metrics? Did they attend seminars, training sessions or some other kind of education about the BSC?

15. Explain the procedure to deliver information / communicate?

16. Did the team members of BSC represent all the areas of the organisations that were expected to use the BSC?

17. Did the implementation of BSC help align key performance measures with strategy at all levels of an organisation?

18. How often the key measures and strategy are discussed in the organisation, can everybody see the results? 